\title{
Social Media Access in K-12 Schools: Intractable Policy Controversies in an Evolving World
}

\author{
June Ahn \\ College of Information Studies \& \\ College of Education, \\ University of Maryland, College \\ Park, USA \\ juneahn@umd.edu
}

\author{
Lauren K. Bivona \\ College of Education, \\ University of Maryland, College \\ Park, USA \\ Ikbivona@gmail.com
}

\author{
Jeffrey DiScala \\ College of Information Studies, \\ University of Maryland, College \\ Park, USA \\ discala@umd.edu
}

\begin{abstract}
The use of social media in public primary and secondary education (K-12) presents schools with numerous obstacles and constraints. Educators might use new media to enrich the classroom, but there are also accounts of grave student misconduct (such as cyber bullying) and legal liabilities for school districts. Education leaders and policymakers face difficult questions of how to promote access and use of technology while safeguarding children. In this paper, we present a frame analysis of several policy forces that govern technology use in K-12 schools. The paper highlights how an evolving, technology-mediated society and traditional education institutions create competing policy frames. These conflicting policy frames lead to intractable controversies that threaten student opportunities to access and learn with new media tools. Such an outcome may have negative repercussions in literacy, learning, and workforce development. This paper discusses several key policy controversies and offers suggestions for ways that K-12 institutions can set policy to facilitate technology in schools.
\end{abstract}

\section{Keywords}

Information Policy, Education Policy, Educational Technology, Media Literacy, Social Media, Youth.

\section{INTRODUCTION}

Recent research on youths, new media, and education paint a stark picture of disconnect between students' learning in and out of school. Internet access is ubiquitous for teenagers in the United States (U.S.), with approximately 93\% reporting regular access. The ways in which youths connect online has also evolved with a rising number of cell phones and mobile devices (Lenhart, Purcell, Smith, \& Zickuhr, 2010). Furthermore, Web 2.0 tools such as social network sites now shape how young people connect, socialize, and learn (Ahn, 2011). However, student use of technology in school lags far behind their experiences outside of school (Cuban, Kirkpatrick, \& Peck, 2001).

Youth responses to the national Speak Up 2009 survey

ASIST 2011, October 9-13, 2011 New Orleans, LA, USA.

This work is licensed under a Creative Commons Attribution 3.0 license. mirror this disconnect. The survey results show that students engage in tremendous learning activities outside of school that are self-directed, interest-driven, and social (Project Tomorrow, 2010). Out of school learning is a common phenomena and contexts such as home, libraries, and museums are key places for youth education. In addition, young people today increasingly learn with digital media tools. For example, youths utilize Facebook for information sharing, access YouTube videos to learn new concepts for school, and participate in online communities that further their interests (Ito, Baumer, Bittanti, boyd, \& Cody et al., 2010; Jenkins, 2006).

Despite young people's desire to incorporate social and digital media into their education, the majority of school districts block access to such tools and technologies (Lemke, Coughlin, Garcia, Reifsneider, \& Baas, 2009). These school policies are often motivated by the obligation to ensure student safety and limit the district's liability. Students can use Facebook to share information, but just as easily use the platform to bully a classmate. The controversies that rise up around online, mobile, and social technologies can result in high profile legal battles for school districts (Cambron-McCabe, 2009; Verga, 2007). Thus, the typical reaction of districts is to block access to new media tools.

Media education advocates note that the repercussions of such policy decisions are potentially far-reaching. For example, Jenkins (2006) asserts that participation in social media and online networks is vital for youth learning and policies that "block access to social networking software in schools and public libraries will further widen the participation gap" (p. 13). However, the issues surrounding youth access to technology are far more complex than simple questions about banning use.

In this paper, we highlight how these dilemmas of practice are fundamental problems of competing policy frames that govern information and technology access in schools. In the following sections, we first introduce the concept of policy frames, which compel researchers to understand the underlying motivations and assumptions of a given policy (Schon \& Rein, 1995). Second, we outline how K-12 public schools (in a U.S. context) are often the battleground for the 
competing motivations, goals, and aims of a broader democratic society. We discuss how major policy influences such as the E-Rate program and the Children's Internet Protection Act (CIPA) frame technology access in K-12 schools.

Third, we review recent research around youth participation in new media and highlight how these evolving trends conflict with past policy frames that governed school technology access. Fourth, we present a qualitative analysis of the technology acceptable use policies (AUPs) in a sample of the largest school districts in the United States. The analysis reveals how access is framed in education policy through frameworks that conflict with the reality of today's student. Finally, we offer recommendations for resolving the current controversies that surround student use of technology in school. We argue that technology can no longer be framed as separate and outside of the typical business of schooling. Instead, educators must frame technology as inextricably embedded within the social and educational elements of school.

\section{FRAME ANALYSIS IN INFORMATION AND EDUCATION POLICY RESEARCH}

Schon \& Rein (1995) observe that policy positions rest on "underlying structures of belief, perception, and appreciation" (p. 23). These elements create what the authors call policy frames. Frames describe the narratives, values, and ideas that convey a particular view of reality for an individual. The frames used by stakeholders, in turn, influence what policy is created and how that policy is implemented.

Policy frames structure how one views the use of technology in society, institutions, or organizations. If technology access and media literacy are the dominant frames, then policies to widen student access to new media are appropriate. If safety is the dominant frame, monitoring and blocking access to new technologies become relevant school policies. Policy frames influence the access and use of new technologies for youths, but no studies to our knowledge have systematically examined the frames that underlie current technology policy in K-12 schools.

This study is motivated by previous scholarly thought in Information and Education Policy. These two fields exist with distinct modes of inquiry, topics, and concerns. However, the topic of technology access in K-12 education institutions offers a unique nexus where frameworks from both areas may converge to provide new insights. The analysis presented here attempts to bridge the concerns of both fields.

Braman (2011) observes that the definition of Information Policy has evolved from a classical focus on government information, to a broader analysis that includes the laws, regulations, and doctrinal positions that influence information creation, access, processing, and use. Rowlands (1996) also identifies a fundamental contribution of
Information Policy studies. Scholars in the field show how the proliferation of new technologies, media, and services often challenge the established policy and regulatory order.

In this context, one can observe how infrastructural policies (such as Education Policy) set the economic and social context for information behavior (Rowlands, 1996). For example, new technologies such as computers, the Internet, and services such as social media, introduce new pressures on educational institutions.

Existing research in Education Policy around technology use in schools has typically focused on the content and structure of student AUPs (Dill \& Anderson, 2003; Flowers \& Rakes, 2000). However, few studies offer frameworks to understand recent controversies surrounding young students and social media. The field of Information Policy fills this gap, and helps researchers frame such controversies as the unique confluence of new media tools, existing institutions, and the information behaviors that arise from these combinations. This study builds from calls by Information Policy scholars to consider value-sensitive, policy frame analysis to understand new information phenomena (Rowlands, 1996; Rowlands, Eisenschitz, \& Bawden, 2002).

\section{TECHNOLOGY ACCESS AND K-12 PUBLIC SCHOOLS: PAST POLICY FRAMES}

A policy frame perspective highlights how various narratives motivate technology access in K-12 education. Numerous policy directives have shaped technology in K12 schools. For example, the influential report $A$ Nation at Risk tightly interwove technology into its concern for a failing education system (National Commission on Excellence in Education, 1983). Nearly 30 years ago, the authors wrote that education must keep pace in a world where computers will penetrate every aspect of life, millions of jobs will require expertise with technology, and technology will transform every industry sector.

Over a decade later, the United States implemented the Erate program, which provided discounts for schools and libraries to build the infrastructure needed to connect to the Internet. Then Vice President, Al Gore, stated of the legislation:

Our nation has taken a great step forward in closing the gap between the information haves and the information have-nots... We are closer to a day when children and their parents and their teachers will walk into a classroom filled with computers linked to the Internet, and not even give it a second thought (Office of the Vice President, 1997).

Finally, the 2010 National Education Technology Plan (U.S. Department of Education, 2010) paints a picture of today's student that is connected to the Internet 24 hours per day, 7 days per week. 
The underlying narratives or policy frames are clear from these examples of national education technology policy over the last three decades. For example, A Nation at Risk makes the general economic argument for technology (National Commission on Excellence in Education, 1983). In this frame, computers must be used in schools to prepare students for a workplace that will be increasingly technological in the future. However, such arguments say little about what must take place in the classroom to prepare students for an uncertain future.

E-rate frames technology in terms of the digital divide, which is a concept that describes gaps in access to technology between rich and poor (Norris, 2001). While couched in arguments about the need to connect students to the information superhighway, E-rate was also justified by a motivation to equalize access to the Internet through schools and libraries.

Finally, recent national education policy recognizes that today's student lives in a world with increased access to information and media tools. No longer are schools the primary arbiter of young people's technology exposure. Youths increasingly interact with technology in a variety of settings (i.e. libraries, homes, and mobile devices).

Early policy narratives focused on the need to expand access to technology and the Internet. Subsequently, policies drove tremendous investment in technology infrastructure in K-12 schools. In 1995 U.S. public schools contained an average of 72 instructional computers. By 2005, this number had reached an average of 154 computers per school. In the same period, the percentage of public schools with Internet access rose from $35 \%$ to $100 \%$ (U.S. Department of Education, 2009).

As access goals were met, fears about student safety and exposure to indecent material on the Internet compelled several technology policies. The most salient is the Children's Internet Protection Act (CIPA). CIPA requires any school that participates in the E-rate program to (1) implement policies that block or filter inappropriate materials, (2) monitor the online activities of minors, and (3) create Internet safety policies (Quinn, 2003). CIPA can be viewed as an incentive-based policy lever because it induces other organizational levels, especially local school districts and schools, to implement additional technology policies. These policies usually come in the form of AUPs that govern student access and use of technology.

At the heart of these various education technology policies are competing frames. The narratives of economic competitiveness and digital divide compel education leaders to expand access to technology for students. However, fears about student safety on the Internet typically induce school organizations to dramatically restrict student use of new tools.

\section{PARTICIPATORY CULTURE AND NEW MEDIA LEARNING: NEW POLICY FRAMES}

The current technology environment is a stark contrast to the times when policies such as E-Rate and CIPA were enacted. Access to computing is widespread. For example, $95 \%$ of U.S. families own a cell phone, $93 \%$ own a home computer, and 94\% have regular Internet users in the family (Kennedy, Smith, Wells, \& Wellman, 2008). Young people from various backgrounds also have tremendous access to technology. A vast majority of teenagers own cell phones, access the Internet, and use social media tools (Lenhart et al., 2010).

Schools are no longer a main provider of computing and Internet access. Homes, public libraries, and now mobile access largely mediate young people's access to new technology (Bertot, McClure, \& Jaeger, 2008; Kennedy et al., 2008; Lenhart et al., 2010). Young people also engage in their everyday activities with social media away from school. For example, surveys of U.S. teenagers find that nearly 75\% use social network sites (SNSs) such as Facebook and Myspace (Lenhart et al., 2010). However, young people are significantly more likely to participate in social network sites when their primary access to the Internet is away from home or school (Ahn, in press).

Such research findings begin to paint a new underlying narrative about young people, technology, and learning. Young people are using social media to learn about their world while away from adult-imposed constraints. Youths navigate their own identities, friendships, love, and social circles through online communities (Ito et al., 2010; Livingstone, 2008). They engage in deep, interest-driven learning by searching online for topics they are interested in, and engaging in self-directed consumption of videos, articles, blogs, and Wikipedia entries (Project Tomorrow, 2010). More importantly, young people participate in their own learning by joining online affinity groups and creating their own media (Ito et al., 2010; Jenkins, 2006). Much of these learning behaviors occur away from the watchful eyes of parents, teachers, and CIPA-compliant, school district Internet filters.

These cultural developments, which Jenkins (2006) describes as a participatory culture, problematize the previous policy frames that governed educational technology. The policy argument of expanding youth access to computing via schools becomes weak if young people prefer to use new media away from school. Furthermore, young people appear to engage in far more creative and compelling learning behaviors with new media outside of school, with few opportunities within classroom walls. This disconnect has compelled some scholars to even question why public funds should be spent to equip schools with computers at all (Cuban et al., 2001).

However, K-12 schools can play a critical role in the area of media education. The story of young people as digital natives is largely misleading (Prensky, 2001). Although young people have grown up surrounded by technology, 
researchers have found that youths exhibit large variability in skills such as online search or assessing the credibility of Internet sites (Druin, Foss, Hutchinson, Golub, \& Hatley, 2010; Hargittai, Fullerton, Menchen-Trevino, \& Thomas, 2010). Furthermore, social media provides powerful opportunities for young people to participate in online communities, but these opportunities also introduce significant risks.

Despite young people's engagement with learning and social media, the typical response by districts has been to block all access to social media tools (Lemke et al., 2009). Such a response is framed by underlying assumptions that are increasingly untenable: (1) that banning access to all potentially objectionable material is a requirement of schools and (2) that schools can continue to separate what happens on campus grounds with out-of-school activities. Social media platforms, with their expanded modes of social interaction, create problems for such education policies.

The result of this changing technological environment is a confusing narrative for K-12 education institutions. How do school institutions promote media education so young people can learn to use new technologies safely and ethically, but safeguard students against negative behaviors? How do K-12 schools expand access to new media tools, while meeting the safety requirements of policies such as CIPA? These questions are what Schon \& Rein (1995) term intractable controversies because the answers rely less on factual information. Rather, solutions stem from the underlying values or policy frames, which parents and educators take up to justify their practices.

The goal of this study is to highlight the underlying policy frames - the implicit assumptions - that lie within the AUPs of K-12 schools. AUPs outline what students are allowed to do with technology. Due to policy requirements from E-Rate and CIPA, most U.S. school districts have a governing AUP document. These documents are a logical source to examine policy frames, because these regulations largely govern students' access and use of technology. In the following analysis we ask three, exploratory research questions:

1. What are the common ways that a sample of U.S. school districts frame student access to technology through their AUPs?

2. What are the underlying policy frames that motivate their access policies?

3. In what ways do these policy frames conflict with the participatory practices that youths can enact with new social media platforms?

\section{RESEARCH METHODS}

In this exploratory study, we analyzed the AUPs of a sample of U.S. school districts. Our sample contains 99 of the largest public elementary and secondary school districts according to the 2010 report from the National Center for Education Research (NCER).

The school districts in our sample govern $15.2 \%$ of U.S. public schools (Sable, Plotts, and Mitchell, 2010). In addition, $21.3 \%$ of the nation's students attend school and $20.5 \%$ of full-time equivalent teachers work in these districts. Within our sample, the number of students per district ranged from 47,448 to 981,690 using 2008-2009 figures (Sable et al., 2010).

Although our sample encompasses a substantial portion of U.S. students and schools, we note that this is a convenience sample. For example, the 99 districts are located within 26 states. Districts in Florida, Texas, and California comprise $45 \%$ of the sample. In addition, districts in our sample come mostly from states on the east, west and gulf coasts. Districts from the middle and northern states are largely absent from our data set.

We also collected documents from five districts that have been applauded for their efforts to integrate social media and new technologies in their schools (Consortium for School Networking, n.d.). The goal of including these districts was to comparatively examine whether these K-12 schools provided different AUP strategies for social media tools in the classroom.

\section{Data Collection}

Our data collection process was iterative and occurred in the 2010-2011 school year. In our initial data collection, we collected any AUP document available on the school district's Web site. These 198 documents consisted of employee AUPs, student AUPs, acceptable use permission forms, and administrative regulations from district policy manuals.

We collected our initial data primarily from school district Web sites. However, some AUPs were located within codes of conduct. A second data collection process was conducted. We attempted to locate administrative regulations, codes of conduct, and acceptable use forms/permissions for each district. In some cases, we also collected district technology plans because they were the only online source of the student AUP. We reviewed the documents for relevance and uploaded 217 documents into Atlas.ti for analysis.

\section{Data Analysis}

We analyzed the 217 policy documents in Atlas.ti. The analysis process proceeded in iterative phases. First, all three authors independently coded the same, small subsample of AUPs. The third author conducted the initial pass through of this sub-sample and developed a set of preliminary codes to describe different elements of the AUPs. The first and second authors then coded the same sub-sample of AUPs with this initial code scheme. The second pass through resulted in the refinement of codes. Several new codes were developed to better describe the 
policy statements in the AUPs and some codes were merged to create more coherency. For example, different AUPs described various disciplinary actions for student misbehavior with technology such as suspension, termination of access, and limitation of rights. These subcodes were combined into a broader code of disciplinary actions during this initial phase. This initial phase of code development also provided opportunities for the three authors to discuss varying interpretations and develop coherent understanding of the policy elements in the AUPs. This first phase resulted in several iterations of coding that resulted in emergent codes that arose from the documents. ${ }^{1}$

We note one limitation of the study from the outset. Traditional metrics such as calculating inter-coder agreement were not run in this study. However, the three themes that this study focuses on (more detail below) consisted of codes that were largely consistent across AUPS. For example, statements of disciplinary action in the AUPs were very clear to identify. It is not surprising that particular policy strategies and underlying policy frames were consistent across many district AUPs. Many AUPs must include similar elements due to requirements of CIPA and E-rate. For example, to obtain E-Rate funds, districts are required to monitor and filter Internet access. Thus, the vast majority of district AUPs include similar language regarding monitoring and filtering. In the codes used in this study, we reached data saturation fairly quickly in terms of different technology policy strategies used by schools.

Finally, we coded the rest of the documents in the sample (split evenly between the authors). Code reports were run for major codes in Atlas.ti, which provided examples of AUP language that reflected particular themes. In this study, we focus on three particular themes that illuminate the underlying policy frames of the school districts' AUPs:

- Information, Media, and Literacy Goals - How did school districts justify their motivations to provide technology access to students in their policies?

- $\quad$ Access - How did school districts frame student access to technology and repercussions for negative behavior?

- Social Media - How did school districts frame social media use (if at all) in their policies?

Reflective memos were then written to identify similarities, and particularly unique divergences, in the framing of these issues across different AUPs.

\section{FINDINGS: REDEFINING TECHNOLOGY ACCESS IN K- 12 SCHOOLS}

In this section, we highlight how existing technology policies in public K-12 schools reflect underlying policy frames that may (or may not) conflict with the participatory media practices of current students.

\footnotetext{
${ }^{1}$ For the complete list of codes used in the analysis, please contact the first author.
}

\section{Information, Media, and Literacy Goals}

Approximately $18 \%$ of the school districts in our sample made explicit mention of information or media literacy goals. The language of these policy statements varied widely across these districts. Some districts structured their AUP goals as objectives. Houston School District's AUP states, "Students will learn how Internet resources can provide valuable educational information" (Houston Independent School District, n.d., p. 2). Similarly, one of Charlotte-Mecklenberg Schools' stated network goals is "to enhance learning opportunities by focusing on the application of skills in information retrieval, searching strategies, research skills, and critical thinking" (CharlotteMecklenberg Schools, 2005, p. 2). These example statements frame access to school technology as critical to achieving particular objectives: access to information and technical skills, such as search, research, and information retrieval.

Other districts framed their policies to justify the need for information and media literacy, or $21^{\text {st }}$ century skills. For example, Anne Arundel County states that, "Student use of technology develops skills in defining, accessing, managing, evaluating, creating communicating, and problem solving" (Anne Arundel County Schools, n.d, p. 22). The student code of conduct in Atlanta Schools asserts their underlying motivation, "Using technology: 1. Requires students to think critically, analyze information and write clearly. 2. Develops problem-solving skills. 3. Cultivates computer and research skills demanded by future employers. 4. Encourages an attitude of lifelong learning" (Atlanta Public Schools, n.d., p. 78).

A variety of subtle, but powerful, policy frames motivate these various AUP statements. By explicitly mentioning information literacy skills as fundamental goals of school, these policy statements create a guiding narrative that foregrounds literacy skills and backgrounds computing as a tool to learn those skills. A policy frame that highlights information literacy development allows room to value student uses of social media. Students who create and share school video projects on YouTube are developing media creation, communication, and lifelong learning skills.

Other policy statements effectively hinder educational uses of social media. Note that only a small percentage of our sample districts made explicit mention of literacy skills as their motivation for technology. Many districts in our sample articulated that technology access for students was for approved educational or academic use only. This type of policy statement reflects a frame that narrowly defines acceptable technology use for approved classroom activities. In such an environment, young people's engagement with YouTube could easily be viewed as frivolous and social, rather than educational. Often, those decisions lie with adults, teachers, and school administrators (and not the students themselves). 
Finally, we also observed examples of innovative policy frames that may serve as models for future AUPs. Several districts explicitly stated the vital responsibility of teachers and educators to promote information or media literacy. More than in other AUPs, the wording of these documents recognizes that the development of literacy skills is not a passive activity. Students will not necessarily develop these skills just by surfing the Internet without guided learning experiences.

For example, New York City's AUP frames Internet access as an essential curricular tool, and states that educators should, "Assist their students in developing the skills to ascertain the truthfulness of information, distinguish fact from opinion, and engage in discussions about controversial issues while demonstrating tolerance and respect for those who hold divergent views" (New York City Department of Education, n.d.). The district's policy also requires teachers to ascertain the appropriateness of online materials and to preview any materials as they plan their lessons with technology.

Such policy guidelines promote (a) the active role of teachers in teaching media literacy, (b) the understanding that youths must learn critical skills to effectively use technology, and (c) part of learning those skills is being able to engage with controversial materials and developing tolerance for different views. These policy frames alleviate the need to strictly block access to the Internet in the name of safety. Rather, teaching students to be critical consumers and creators of online material may more align with the challenges young people will face in a participatory, social online world.

\section{Access}

We observed a diverse array of philosophies concerning technology access in the sample of school AUPs. Many districts framed access as a privilege or responsibility, not a right. For example, approximately $50 \%$ of the districts in our sample state that access is a privilege, not a right.

School districts exhibited different strategies to involve parents in the decision to allow young people access to the Internet and computing at school. A substantial number of districts also required students to sign an agreement form to access school technology. In our sample, $48 \%$ required parents to sign an opt-in form to give their children permission to use technology in school. Approximately $16 \%$ of the districts allowed parents to either grant or deny permission. In $19 \%$ of districts, students were automatically given access to the Internet, but parents could opt-out of their child's access to the Internet either by filling out an opt-out form or by sending in a note to the school.

We also observed a few divergent policy statements. For example, New York City's AUP framed Internet access as a curricular offering and did not offer the ability of parents to opt their child out of Internet access at school. The NYC AUP states, "As with other curricular offerings and tools, parents do not have a general right to opt their child out of classroom use of the Internet. . . Parents moreover, are strongly encouraged to discuss and monitor their child's school Internet use and to discuss any issues or concerns that they may have with the school's teacher and administrators" (New York City Department of Education, n.d.).

Different policies regarding access reveal the wide diversity in how access is implemented in public schools. For example, because access is so often framed as a privilege, AUPs also state that access may be denied or taken away. Nearly all of the AUPs (95\%) stated that misuse could result in the suspension or termination of access. Such a framework underscores particular values. Technology access is a privilege that is separate from the natural business of school. It is a privilege to be earned and can be taken away. These narratives conflict tremendously with statements that suggest technology is a vital requirement for learning information literacy skills. Such policy frames also diverge from young people's experiences, where technology is inextricably embedded in their learning activities.

These conflicting policy frames connect to dilemmas of practice in classrooms. Consider a teacher who has spent considerable time planning lessons that use the Internet. One or two students are caught breaking a rule in the district's AUP and are banned from using the school Internet connection. In such a situation, the teacher must now abandon the lessons or create alternative lessons for these singular students. Such pressures inhibit teachers' willingness to integrate new technologies into their practices, and thus student opportunities to use technology in school.

Policymakers and educators must rethink the role of technology in school to alleviate the intractable controversy of expanding access to technology and banning access for bad behavior. Different narratives play a deep role in reframing the concept of access. For example, textbooks are an integral element of classroom learning and students are given widespread access to this technology. If a student physically assaults a peer with a textbook, it is unlikely that they are then banned from using books thereafter. Rather, teachers and school administrators typically address the behavior (bullying), because the technology (textbook) is a vital part of the business of schooling.

This example of a different policy frame alters how one conceptualizes technology access in schools. A student might bully another peer on Facebook, but banning access to the school Internet or the website is unlikely to stem the behavior. Young people merely continue their social media activities on their mobile phones or outside of school grounds. These realities have resulted in current legal battles concerning the role of schools in cyber bullying cases or student misconduct on the Internet (Doninger $v$. Niehoff, 2008; J.S. v. Blue Mountain School District, 2010; 
Layshock v. Hermitage School District, 2010; Wisniewskiv. Board of Education of Weedsport Central School District, 2007). The emerging understanding from these cases is that schools are often compelled to respond to student misconduct online even if they block access to websites on school grounds (as long as the misconduct impacts a student's educational experience). However, as of this writing, this issue remains contested in the courts.

A narrow focus on access as a binary question (yes or no) severely neglects the true issue of young people's behavior with technology. Social media does not cause a behavior such as cyber bullying. Instead, an individual has decided to bully a peer through available channels (and today that might be social network sites or cell phones). In the past, this behavior might have occurred in a hallway or locker room. Merely banning access to a tool ultimately prevents students from learning how to properly use technology.

Allowing wider access to new media tools, while addressing negative student behavior is a much more complex problem for educators. Policy plays a subtle but powerful role in framing a solution. Districts can make clear their motivation behind expanding access for students (i.e. to promote information and media literacy skills that are vital in today's world), which frames an underlying foundation to justify allowing a wider array of new media in classrooms. District AUPs might move away from framing access as a privilege that is (a) separate from the real business of schooling and (b) can be taken away as discipline for student misconduct. Instead, student misconduct with technology might be viewed as an issue of behavior (with the salient repercussions) and not an issue of technology alone.

Finally, a critical issue for educators and school leaders is communicating new policy frames to stakeholders. Creating opportunities for parents, and equally importantly students, to opt-in or opt-out to the school's technology resources provide powerful opportunities to explain and communicate a district's underlying philosophy with technology (see Cyber Safety Campaign, n.d.). Access is no longer a binary issue of allow or disallow. Instead, multiple stakeholders (parents, students, and teachers) must coordinate to provide wider access to new media and deal with safety concerns as they arise.

\section{Social Media}

The AUPs in our sample varied in how they framed the use of social media in the classroom. The majority of district AUPs made no mention of social media tools. Fourteen percent of districts banned social media entirely. Thirtyfour percent of districts mention permitting the use of social media tools with certain restrictions. However, of these districts, seven only mention chat rooms, perhaps the oldest form of online synchronous communication. This finding suggests that some policies regarding social media tools may be slightly outdated.
Some districts permitted access to social media with provisions or a required responsibility on the part of the student. In Aldine Independent School District, students must first be instructed on "the safe use of the Internet, including safety precautions for e-mail, online chat, instant messaging, texting and other online behaviors" before using social media tools (Aldine Independent School District, 2009 , p. 2). In Boston, the user agreement that students must sign includes a provision that students will use all means of communication responsibly (including social media tools like blogs, wikis, instant messaging, and discussion boards). Students in Boston must also contractually agree that they "understand that what [they] do on social networking websites should not negatively impact the school learning environment and/or [their] fellow students, teachers and administrators" (The Boston Public Schools Communication Office, 2010, p. 45).

Twenty-four percent of districts allowed access with approval or supervision from a teacher or the school's administration. For example, in the AUP of Anchorage School District teachers are required to create a plan that defines their use of online tools, how students will use the system, what methods will be used to monitor student behavior, and what students will do in the system. The school's principal must approve this plan before the teacher may integrate social media tools into the classroom. In addition, parents must sign permission forms and the district's Technology Department must be informed of teacher plans to use social networking (Anchorage School District, 2010).

While some AUPs implied that social media might be useful classroom tools, very few districts explicitly noted that social media had potential educational value and use in the classroom. Granite School District's social networking policy (2010) states, "The Board of Education recognizes the potential pedagogical value, as well as potential hazards of social networking. The following policy is promulgated to protect students and personnel" (p. 1). Granite School District outlined specific procedures for social networking use. Educators need to propose the online community to the administration and students may not participate unless they have parent permission. The policy states that educators "are responsible for ensuring that student posts on school related sites which violate laws or policies are removed immediately and appropriate" and "are responsible for all content." Additionally, administrators must be given access to the social media site for monitoring purposes (Granite School District, 2010).

Finally, we examined policies from a few districts that were lauded for their social media strategies (Consortium for School Networking, n.d.). For example, Birdville Independent School District (BISD) (n.d.) states in their AUP:

As a district, Birdville ISD recognizes the value of student, teacher, parent, and community 
interaction on social networking sites that are designed for specific educational purposes and directly tied to BISD Curriculum and Instruction. Collaboration, resource/information sharing, online tutoring, etc. can all be facilitated by the judicious use of educational internet/Web 2.0 networking tools/web pages. Sites such as Facebook, Edmodo, Twitter, blogs, wikis, other Web 2.0 internet resources, etc. are very beneficial to our student and parent community (p. 1).

Duxbury Public Schools (2010) framed blogs, podcasts, and other social media tools as "extension[s] of the classroom" (p. 2). This statement was used to preface rules regarding the correct use of tools inside and outside the classroom. However, it also implies that social media can bridge the school and home. The Duxbury AUP also states that "Online communication is critical for Millennial Learners to apply 21st Century Skills and employ tools such as interactive websites, blogs, video conferencing, podcasts, etc which offer authentic opportunities for students to express and share information" (Duxbury Public Schools, 2010, p. 1).

A stark finding from our analysis was that few school districts made explicit mention of social media tools in their AUPs. However, the examples we cite here offer a range of policy frames that other districts may enact. On one end of the spectrum are policies that ban social media tools altogether. Such AUPs alleviate liabilities for schools in the short term, but may ultimately have profound long-term repercussions. Lack of technology use in classrooms and young people's disconnect from school may continue.

On the other end of the spectrum are districts that communicate a full intention to use social media tools in the classroom. However, future studies are needed that examine how different policy mechanisms affect teachers' and library media specialists' uptake of social media tools in their practices. If teachers must overcome bureaucratic obstacles to integrate a social media tool (i.e. a proposal, parent forms, student forms, and approval from principals and district offices etc.), such policy levers may effectively hinder social media use in the classroom. Studies that can forward understanding of how information policy (AUPs) influences educator practices may make a large contribution.

\section{DISCUSSION}

This study offers one of the first systematic analyses of technology policies in U.S. K-12 public schools that highlight the underlying policy frames of AUPs. Information policy, in the context of technology access in $\mathrm{K}-12$ education, is much more complex than questions of funding and the number of computers in schools. This study shows how individual school districts frame technology use for students and how those motivations suggest different philosophies for educational technology in an era of social media.
We highlight how policy language sets the educational goals of technology in schools. Those goals play a subtle but grounding role in how one justifies the use of various tools for learning. Some districts promote media literacy and thus include within their purview, new media tools that may be problematic at first to classroom practices. Other districts restrict technology use to approved classroom activities that are often left up to the decisions of adults, administrators, and teachers.

Policy frames around access also set the stage for educational uses of technology. Many districts consider technology access a privilege that can be taken away. We highlight how such a framework ignores the underlying mechanisms of student misbehavior, and can lay the blame on technology alone. Educators are not apt to ban textbooks in the classroom, but can easily justify eliminating new technologies. In an evolving world where young people learn with ubiquitous access to information and media, such policy frames may unnecessarily restrict students and increase their disconnect from school.

Finally, school districts are currently in a period of rapid change as they catch up to the realities concerning social media. Many school districts ban access to social media tools and few integrate social media into their technology policies. Of those that do consider social media, there is great variation in their strategies. Some fully embrace (in stated policy at least) social media's potential for reshaping education, better engaging youths, and improving learning. Others allow new media tools, but require extensive bureaucratic processes to ensure student safety. These diverse examples reveal a spectrum of frames, or narratives, about how school leaders view the role of technology in education.

The limitations of this study also highlight future avenues for research and practice. First, the use of new media in education settings requires a complex blend of factors. Policy plays the role of setting fundamental values and processes in place. However, available resources, teacher motivations, curriculum, and students all play roles in integrating new technologies in the classroom. This exploratory study only considered policy as one factor of technology integration. Future studies that can link the policy frames of a given district or school to the actual practices of educators can make a significant impact on teaching, learning, and educational change. What are teachers' uses of social media like in districts that restrict access? How do regulatory constraints (such as requiring parental and community approval) influence what teachers do in the classroom? These types of questions can contribute new insights into the use of new media tools for learning.

Second, looking at any single AUP alone does not offer many insights into how to best evolve new policies in K-12 schools. However, strategies culled from different school 
districts combine to offer some practical ways to change information policy in education:

- The explicitly stated goals of a district's technology policy may frame its capacity to incorporate new technology tools. For example, a stated goal to promote critical thinking and media literate students is a starkly different frame than restricting technology use to only approved activities.

- Treating technology as a privilege frames it as separate from the usual business of schooling. Framing technology as integral to learning motivates different reactions when students misbehave with the tool. Instead of banning, other more productive actions come to fore when educators frame technology as a fundamental part of learning.

- Social media introduces controversy because it blurs the line between school and the outside world. Policies are needed that clarify how schools will deal with outof-school behavior as well as in-school conduct.

Ultimately, as technology continues to blur the boundaries of school, policies must incorporate parents and student responsibilities with new media. The benefits of incorporating new social technologies are numerous for youths. Young people learn with social media regardless of what they do in school, and thus the disconnect may continue to grow with inaction. However, a thoughtful integration of new tools may broaden student perspectives, help them become literate and powerful contributors to a technological society, expose them to new ideas, and expand their opportunities to learn about their world.

\section{REFERENCES}

Ahn, J. (2011). The effect of social network sites on adolescents' social and academic development: Current theories and controversies. Journal of the American Society for Information Science and Technology, 62(8), 1435-1445.

Ahn, J. (in press). Digital divides and social network sites: Which students participate in social media? Journal of Educational Computing Research, 45(2).

Aldine Independent School District. (2009). Aldine independent school district internet acceptable use guidelines and consent form. Retrieved from https://www.aldine.k12.tx.us/ePortal/document_manage ment/docs/2009_Student_AUP_English.pdf.

Anchorage School District. (2010). Anchorage School District: Internet \& electronic communication guidelines. Retrieved from

http://www.asdk12.org/forms/uploads/InternetGuidelines. pdf.

Anne Arundel County Public Schools. (n.d.). Student handbook: A guide to student rights and responsibilities, 2010-2011. Retrieved from http://www.aacps.org/html/studt/studenthandbook.pdf.
Atlanta Public Schools. (n.d.). 10|11 student handbook: Journey to excellence. Retrieved from http://www.atlantapublicschools.us/18611010817122770/ $\mathrm{lib} / 18611010817122770 /$ Student_Handbook_20102011_08242010.pdf.

Bertot, J. C., McClure, C. R., \& Jaeger, P. T. (2008). The impacts of free public internet access on public library patrons and communities. Library Quarterly, 78(3), 285301.

Birdville Independent School District. (n.d.). Guidelines: District educational social networking sites. Retrieved from

http://schools.birdvilleschools.net/it/lib/it/Guidelines_for _Social_Media.pdf.

Boston Public Schools Communications Office. (2010). 2010-2011 Guide to the Boston Public Schools for Families and Students. Retrieved from http://www.bostonpublicschools.org/files/BPS\%20Guide \%20SY11\%20English.pdf.

Braman, S. (2011). Defining information policy. Journal of Information Policy, 1, 1-5.

Cambron-McCabe, N.H. (2009). Students' speech rights in an electronic age. West's Education Law Reporter, 242, 493-503.

Charlotte-Mecklenberg Schools. (2005). Student internet use. (Policy code IJNDB-R). Retrieved from http://www.cms.k12.nc.us/cmsdepartments/ts/Documents /Internet $\% 20$ Acceptable $\% 20 U$ se $\% 20$ Policy.pdf.

Consortium for School Networking. (n.d.). Acceptable use policies in web $2.0 \&$ mobile era. Retrieved on May 18, 2011 from

http://www.cosn.org/Initiatives/Web2/AUPGuide/tabid/8 139/Default.aspx.

Cuban, L., Kirkpatrick, H., \& Peck, C. (2001). High access and low use of technologies in high school classrooms: Explaining an apparent paradox. American Educational Research Journal, 38(4), 813-834.

Cyber Safety Campaign. (n.d.). Family resources. Retrieved on May 23, 2011 from

http://www.bpscybersafety.org/familyresources.htm.

Dill, B.J. \& Anderson, R.E. (2003). Ethics-related technology policies in schools. Social Science Computer Review, 21, 326-339.

Doninger v. Niehoff, 527 F.3d 41 (2d Cir. 2008).

Druin, A., Foss, E., Hutchinson, H., Golub, E., \& Hatley, L. (2010). Children's roles using keyword search interfaces at home. Proceedings of the $28^{\text {th }}$ International Conference on Human Factors in Computing Systems (CHI'10), 413-422.

Duxbury Public Schools. (2010). Internet connectivity and technology tools: Duxbury Public Schools acceptable use guidelines. Retrieved from 
http://www.duxbury.k12.ma.us/documents/AUG5-122010.pdf.

Flowers, B.F. \& Rakes, G.C. (2000). Analyses of acceptable use policies regarding the Internet in selected K-12 schools. Journal of Research on Computing in Education, 32(3), 351-365.

Granite School District. (2010). Article X.C.3. social networking policy. Retrieved from http:/www.graniteschools.org/departments/superintenden t/districtpolicies/Instructional\%20Technology/3.\%20Soci al\%20Networking\%20policy.pdf.

Hargittai, E., Fullerton, L., Menchen-Trevino, E., \& Thomas, K. Y. (2010). Trust online: Young adults' evaluation of web content. International Journal of Communication, 4, 468-494.

Houston Independent School District. (n.d.) Acceptable Use Policy for Electronic Services for Students. Retrieved from

http://www.houstonisd.org/HISDConnectEnglish/Images/ PDF/StudentAUP-2010.pdf.

Ito, M., Baumer, S., Bittanti, M., boyd, d., \& Cody R., et al. (2010). Hanging out, messing around, and geeking out: Kids living and learning with new media. Cambridge, MA: MIT Press.

Jenkins, H. (2006). Confronting the challenges of participatory culture: Media education for the 21st century. Chicago, IL: The MacArthur Foundation.

J.S. v. Blue Mountain School District, 593 F.3d 286 (3d Cir. 2010).

Kennedy, T. L. M., Smith, A., Wells, A. T., \& Wellman, B. (2008) Networked families. Washington DC: Pew Internet \& American Life Project.

Layshock v. Hermitage School District, 593 F. 3d 249 (3d Cir. 2010).

Lemke, C., Coughlin, E., Garcia, L., Reifsneider, D., \& Baas, J. (2009). Leadership for Web 2.0 in education: Promise and reality. Culver City, CA: Metiri Group.

Lenhart, A., Purcell, K., Smith, A., \& Zickuhr, K. (2010). Social media \& mobile internet use among teens and young adults. Washington DC: Pew Internet \& American Life Project.

Livingstone, S. (2008). Taking risky opportunities in youthful content creation: Teenagers' use of social networking site for intimacy, privacy, and selfexpression. New Media \& Society 10(3), 393-411.

National Commission on Excellence in Education. (1983). A nation at risk: The imperative for educational reform. Retrieved from http://www2.ed.gov/pubs/NatAtRisk/index.html.

New York City Department of Education. (n.d.). Internet acceptable use policy. Retrieved from
http://schools.nyc.gov/Offices/EnterpriseOperations/DIIT /WebServices/iaup/default.htm\#preamble.

Norris, P. (2001). Digital divide: Civic engagement, information poverty, and the internet worldwide. New York, NY: Cambridge University Press.

Office of the Vice President. (1997). Statement of the vice president on the FCC E-rate decision. Retrieved on January 13, 2011 from http://www2.ed.gov/PressReleases/05-1997/97-0507.html.

Prensky, M. (2001). Digital natives, digital immigrants: Part 1. On the Horizon, 9(5), 1-6.

Project Tomorrow. (2010). Creating our future: Students speak up about their vision for $21^{\text {st }}$ century learning. Retrieved from http://www.tomorrow.org/speakup/pdfs/SU09NationalFi ndingsStudents\&Parents.pdf.

Quinn, D.A. (2003). Legal issues in educational technology: Implications for the legal system. Education Administration Quarterly, 39(2), 187-207.

Rowlands, I. (1996). Understanding information policy: Concepts, frameworks, and research tools. Journal of Information Science, 22(1), 13-25.

Rowlands, I., Eisenschitz, T., \& Bawden, D. (2002). Frame analysis as a tool for understanding information policy. Journal of Information Science, 28(1), 31-38.

Sable, J., Plotts, C., and Mitchell, L. (2010). Characteristics of the 100 largest public elementary and secondary school districts in the United States: 2008-09 (NCES 2011-301). U.S. Department of Education, National Center for Education Statistics. Washington, DC: U.S. Government Printing Office.

Schon, D. A., \& Rein, M. (1995). Frame reflection: Toward the resolution of intractable policy controversies. New York, NY: Basic Books.

U.S. Department of Education. (2009). Digest of education statistics: 2009. Washington DC: National Center for Education Statistics. Retrieved on January 15, 2011 from http://nces.ed.gov/programs/digest/d09/tables/dt09_425.a $\mathrm{sp}$.

U.S. Department of Education. (2010). Transforming American education: Learning powered by technology. Washington DC: Office of Educational Technology, National Education Technology Plan 2010.

Verga, R.J. (2007). Policing their space: The First Amendment parameters of school discipline of student cyberspeech. Santa Clara Computer \& High Technology Law Journal, 23.

Wisniewski v. Board of Education of Weedsport Central School District, 494 F.3d 34 (2d Cir. 2007). 